
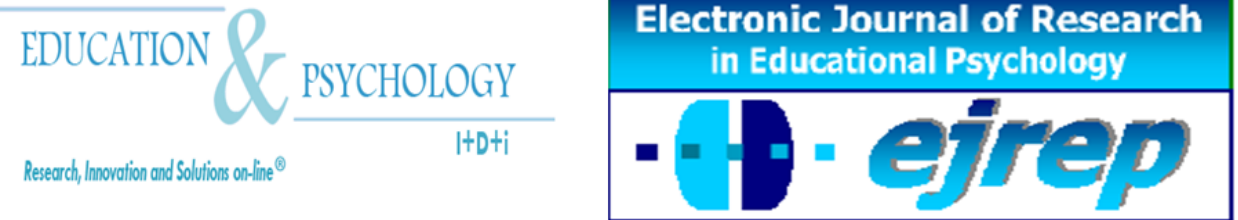

Editorial EOS

\title{
The Perceptions of Prospective Teachers on the Democratic Aspects of the Constructivist Learning Environment
}

\author{
Erdal Bay, Kerim Gündoğdu, Halil Ibrahim Kaya
}

K.K. Faculty of Education, Department of Educational Sciences, Atatürk University, Erzurum

Turkey

Correspondence: $\quad$ Assist. Prof. Dr. Kerim Gundogdu. Atatürk University. Turkey.

E-mail: gundogduk@gmail.com

(C) Education \& Psychology I+D+i and Editorial EOS (Spain) 


\begin{abstract}
Introduction. The nations which have the aim to create democratic societies should also realize the same ideals in educational practices. Related literature declare that learning environments based on constructivist approach is assumed to be democratic. In line with this frame, the aim of this study is to determine the perceptions of prospective teachers on the democratic aspects of constructivist learning environments.
\end{abstract}

Method. The study was conducted with 229 prospective teachers who attended the Measurement and Evaluation course. In this study, learning environment which supported democratic values such as learner independence-autonomy, appreciation-respect, justice, respect for different ideas, acceptance of differences, shared understanding, collaborative work, responsibility and critical thinking, were constructed. Democratic constructivist learning environment scale, which was developed by the researchers, was utilized to obtain data. The scale whose validity and reliability was tested comprises 56 items.

Results. The findings based on the perceptions of the prospective teachers revealed that the learning environments established in line with the principles of constructivist approach were democratic.

Discussion and conclusion. On the basis of the data obtained from the prospective teachers that teacher training institutions should take into consideration of designing learning environments regarding constructivist approach. Prospective teachers' perceptions also suggested that establishing a democratic learning atmosphere may teach them how democracy affects the minds of minors in schools as the future citizens.

Keywords: Constructivism, democratic environmens, teacher training

Received: 09/23/09 Initial Acceptance: 09/24/09 Definitive Acceptance: 11/25/09 


\section{Percepciones de los futuros docentes sobre aspectos democráticos del entorno de aprendizaje constructivista Resumen}

Introducción. Las naciones que tienen el propósito de crear sociedades democráticas también deberían desarrollar los mismos ideales en las prácticas educativas. La información relacionada menciona que los ambientes de aprendizaje basados en enfoques constructivistas se asumen ser democráticos. Con respecto a ello, el propósito de este estudio es determinar las percepciones de los educadores potenciales sobre los aspectos democráticos de los ambientes de aprendizaje constructivistas.

Método. El estudio se llevó a cabo con 229 educadores potenciales quienes asistieron al curso de Evaluación y Valoración. En este estudio, se crearon ambientes de aprendizaje que soportan valores democráticos tales como autonomía del estudiante, valoración del respeto, justicia, respeto por la libre opinión, aceptación de diferencias, entendimiento compartido, trabajo colaborativo, responsabilidad y pensamiento analítico. La escala democrática de ambientes de aprendizaje constructivistas, la cual fue desarrollada por los investigadores, se empleó para obtener datos. La escala, que fue evaluada en cuanto a su validez y fiabilidad, consta de 56 elementos.

Resultados. Los hallazgos basados en las percepciones de los educadores potenciales revelaron que los ambientes de aprendizaje establecidos de la mano de los principios del enfoque constructivista fueron democráticos.

Debate y conclusión. A partir de los datos obtenidos por parte de los educadores potenciales acerca de que las instituciones educativas deberían tener en cuenta el diseño de ambientes de aprendizaje relacionados con el enfoque constructivista. Las percepciones de los educadores potenciales también mencionan que la creación de un entorno de aprendizaje democrático puede enseñarles qué tanto afecta la democracia las mentes de los menores en las escuelas como futuros ciudadanos.

Palabras claves: Constructivismo, ambientes democráticos, capacitación de los educadores

Recibido: 23/09/09 Aceptación Inicial: 24/09/09 Aceptación Definitiva: 25/11/09 


\section{Introduction}

Nations which have the ideals to create democratic societies should also realize the same ideals in educational activities. According to John Dewey (1966), if we want to talk about democracy, educational settings should also be democratic. The only way for teachers who are expected to shape the future can only contribute to this aim if they train themselves professionally in democratic settings.

For many years learning environments based on constructivist approach, which are thought to be effective in educational processes, are considered to be democratic learning environments. In this study, learning environments based on constructivist approach were structured in relation with pedagogic formation in teacher education as was recent efforts by the Ministry of National Education in Turkey. Prospective teachers' perceptions on the democratic aspects of these learning environments are sought. So, the purpose of this study was to investigate the perceptions of prospective teachers with regard to democratic constructivist learning environment established for a pedagogy course.

\section{Democratic Constructivist Learning Environment}

In democratic societies school is the basic institution through which democracy is taught and sustained. O'Hair, McLaughlin and Reitzug (2000) state that the main aim of schools in terms of democracy education is to teach learners basic life skills and help them conceptualize democracy by providing them with authentic teaching activities based on real life situations. In this way, individuals are expected to adapt to social life better. According to James Bank (cited in Campbell, 2000), in order to raise effective citizens in schools, democratic systems have the task of transmitting students the knowledge on democratic life, its values and skills. Gerzon (1997) indicates that there is no other way of teaching democracy unless the principles of democracy are implemented. This statement can be parallel with Dewey's (1966) ideal that classes are the mirrors of democratic societies.

Rowland (2003) stated that universities should follow teaching methods that emphasize student independence and participation. Universities through a formal curriculum that stresses teacher-student relationship and communication can help students improve their inquiry skills and critical thinking and therefore contribute to the democracy in several dimen- 
sions. These ideas clearly imply that to in order to create democracy in schools, classrooms and learning environments should also be democratic. As Holmes (1991) defines democratic classrooms as places where individuals' rights are protected and respected, life based on group work and collaboration is supported and protected, and communication among members is allowed.

The relevant literature (Audigier, 2000; Goodman, 1989; LeBlanc \& Skaruppa, 1997; Passe, 1996; Radz, 1983) implies that an environment, which has a collaborative culture and where students' affective skills and independence are supported, is ideal for democracy. A democratic classroom is based on student independence and self-regulation. In this case, in a constructivist classroom power and control are shared because empowerment of students is placed at the centre of the constructivist philosophy of teachers. Empowerment and independence of students can only be provided if they are encouraged to be active and ask questions in class.

Glickman (1993) also clarifies that when democratic learning settings were designed in schools, it was seen that students could better learn in cognitive level, work on problems more effectively and responsibly and acquire free/self- ordering skills. For example, in a study conducted by Kıncal and Işık (2003) on the characteristics of democratic environments equality, freedom, justice, honesty, search for good, collaboration, confidence, sensitivity and responsibility were determined as crucial democratic values. In addition, tolerance for diversity, safety, peace, development, perfection and effectiveness were also identified as other democratic values.

Constructivist learning environment implies a setting where learners collaboratively construct knowledge through problem solving and the use of learning tools and knowledge sources, and give support each other in this learning process (Akar, 2003; Kesal \& Aksu, 2005; Soon, Apan, \& Huabing, 2001; Tynjala, 1999). Such environments are not places where information is simply transmitted. It is a place where intellectual activities are provided, inquiries and research are practiced; thinking, conceptualization, problem solving and learning skills are improved (Şaşan, 2002). Regarding this issue, Pankratius and Young (1995) state that in learning environments which are designed based on constructivist learning principles, students are encouraged to evaluate their knowledge and belief and explain them. Jonassen 
(1994) also describes constructivist learning environments as contextual, interactive, purposeful, collaborative, complex, reflective and active.

Constructivist learning environment facilitate collaborative education through social interaction and discourages student competition (Abdal-Haqq, 1998; Oğuz, 2005; Terhart, 2003). Through this, learners can develop their own perspectives, look at the problem from different angles and construct meanings and solutions (Lin Hsiao, 2004). In this process when participants have things to say, they are allowed to construct new ideas (Saban, 2004). This example clearly shows that 'shared understanding' is one of the most important dimensions of constructivist approach. According to Kim (2001) shared understanding is a way of understanding among individuals whose interaction is based on common interests and assumptions that shape their communication.

Another aspect of constructivist learning environments is to encourage learners for individual ownership and voice in the learning process beginning from the kindergarten to upper levels. Learners, especially in lower grades, want to have control and responsibility for their own learning. Teachers play the facilitator role for learners in their goal settings (Gündoğdu, 2006; Honebein, 1996). Then, learners make decisions about how to learn, what subject matters and subtopics they will study and what problem solving methods they will use in accordance with their learning pace and study methods (Honebein, 1996; Kesal \& Aksu, 2005; Moallem, 2001; Özden, 2003).

In constructivist learning environments, it is important for learners to have advanced problem solving, analysis, synthesis, and critical thinking knowledge and skills (Murphy, 1997; Terhart, 2003; Tynjälä, 1999). In these learning environments students are given the opportunity to express themselves in the learning process. Learners' ideas are always taken into consideration and students are encouraged to express their ideas. Moreover, if necessary learning strategies and content are modified as to the learner responses (Honebein, 1996; Kesal \& Aksu, 2005; Moallem, 2001; Özden, 2003; Savaş, 2007).

Such learning environments provide multiple representations of reality and reflect the complexity of the real world and foster multiple perspectives. The philosophical foundations of this constructivist approach are related with relativism. Constructivist process differs from one person to another due to different individual characteristics and contextual settings. 
Learners may develop different constructs even though they are taught by the same teacher who applies the same learning processes. Therefore it can be argued that there is no single reality in the learning environment. In such an environment multiple presentations of knowledge and concepts are provided. Learners must engage in activities through which they can construct their multiple interpretations and use multiple thinking and problem solving methods (Kesal \& Aksu, 2005; Tynjala, 1999).

In a constructivist learning environment teachers also have the roles of monitoring learners, providing sources, feedback, cues, helping students analyze their own learning processes and evaluate themselves (Herrington \& Kervin, 2007; Lee \& Butler, 2003; Postholm, 2006; Tynjala \& Hakkinen, 2005). In the relevant literature of teachers' constructivist roles, it is implied that teachers are expected to facilitate learning and interaction in the classroom. In this process teachers help groups to design their projects, organize meetings with groups and help them find the necessary materials and sources. For this aim teacher goes around the classroom, helps the group in need and if necessary s/he joins the group activities as a member and tries to foster students' learning. Teacher encourages students and shows them the alternatives instead of imposing ideas on them. Teacher helps students improve their research and study skills and monitors the learning process of the groups (Abdal-Haqq, 1998; Demirhan \& Demirel, 2002; İşman, 2003; Kesal \& Aksu, 2005; Koç, 2007; Murphy, 1997; Savaş, 2007; Tezci \& Dikici, 2003; Yaşar, 1998).

Democratic classroom environment emphasizes shared responsibilities and decision making. Active and collaborative learning, the significance of individual and social life experiences, flexible classroom rules, and emphasis on student learning rather than teacher performance defines a democratic classroom environment (Dewey, 1916; Lester and Onore, 1990). These characteristics also imply the characteristics of constructivist learning environments. Dockery (2008) states that, due to the nature of constructivist approach learning environment should be democratic. In addition to this, Gray (1997) implies that in constructivist learning environments activities are learner-centered, students are actively involved, teachers encourage learners and support student responsibility and independence. In other words, constructivist learning environments are democratic.

Learning experiences are designed; students can make their own decisions; plan their own learning and practice, monitor their own improvement and evaluate their own work in 
constructivist learning environment (Gagnon \& Collay, 2001). These practices support learner independence (autonomy) due to the democratic characteristics of the environment. In such a collaboration process, learners also value the ideas of the group members, solve their conflict within the group, listen to the presentations of other groups carefully, express their ideas in a respectful manner and the presenting group meet any kind of criticism with matureness. These all imply one of most important aspects of democratic learning environment which is respect for different ideas-accepting differences. Listening to the ideas of others, participation in decision-making and supporting the independence of learners are important indicators of respect for learners and appreciation of learner behavior. In such a learning environment learners are given the opportunity to express their ideas about the method the teacher uses and the works of other groups. This democratic approach contributes to the development of critical thinking.

New alternative assement strategies have been observed in most of the contemporary teacher training institutions (Coll, Rochera, Myordomo \& Naranjo, 2007). These strategies are widely used in constructivist school settings. There are differences in the evaluation processes in constructivist learning environments. In these learning environments learners prepare evaluation tools and criteria together with their teachers. Learners are not compared at all. Learners are aware of the fact that evaluation is not for the aim of comparing students but only for contributing to the learning process (Bahar et al., 2006; Effie, 2004; Semerci, 2001; Taras, 2001). In this evaluation process, apart from teacher evaluation, students also evaluate themselves and their peers. Teacher evaluations may not be valid, reliable and clear in some cases. Learners may sometimes be in a better status than their teacher in evaluating the work of their peers. These processes also foster justice in evaluations. The participation of learners in the learning process helps them in the process of becoming independent and self-directed learners. Especially self-evaluation process provides opportunities for students to reflect their own developments and criticize themselves (Bahar et al., 2006).

Learners evaluating themselves and their peers are an important aspect of democratic learning. Constructivist learning environment allow learners to participate in the evaluation process. Related to this, Boud (1995) states that if students are left out of the assessment and evaluation process they are in fact isolated from taking responsibilities. Parallel to this idea, Dearing (1997) emphasizes that especially in higher education assessment and evaluation is of great importance, and if we want to raise creative, just and democratic individuals, students should be allowed to take part in evaluation process. Besides, these processes can be more 
objective, if students are allowed to evaluate themselves and their peers. Kaye (1992) indicates the importance of the collaborative characteristic of a constructivist learning environment. In this collaborative study process students are expected to work in harmony, support the idea that learners in team will positively affect learning process, involve in decision making, enjoy working together, and have different roles. Having shared understanding in these processes is an important characteristic of a democratic learning environment.

Finally, constructivist learning environments have the aim of creating a democratic learning environment through supporting justice, shared understanding, respecting learners, accepting differences, and critical thinking. The purpose of this study is to investigate the perceptions of prospective teachers on how democratic constructivist learning environments are.

\section{Research Questions}

1. What are perceptions of prospective teachers on whether or not constructivist learning provides:

* Shared understanding

* Justice

* Respect for different ideas

* Critical thinking

* Possibility

* Appreciation \& respect

* Independence \& autonomy

2. Is there any correlation between these dimensions of democratic learning environment?

\section{Method}

\section{Participants}

The sample of the study comprises 229 prospective teachers (101 female and 128 male) who are registered to study in K.K. Faculty of Education at Erzurum Atatürk University, Turkey and attended the 'Measurement and Evaluation' course as part of the pedagogy 
(teacher training) program in 2008-2009 academic year. Their age ranges varied between 20 and 24. The sampling is distributed according to the departments as follows:

Table 1. Frequency and percentage values of the sample

\begin{tabular}{|c|c|c|}
\hline Department & $\mathbf{N}$ & $\%$ \\
\hline Psychological Counseling and Guidance & 26 & 11,4 \\
\hline Geography & 38 & 16,6 \\
\hline Turkish Language and Literature & 40 & 17,5 \\
\hline Mathematics & 41 & 17,9 \\
\hline History & 42 & 18,3 \\
\hline Philosophy & 42 & 18,3 \\
\hline Total & 229 & 100,0 \\
\hline
\end{tabular}

The table shows that the number of the prospective teachers included in the sample is almost equally represented with respect to the departments.

\section{Instrument}

In this study, 'Democratic Constructivist Learning Environment' scale (Bay, Kaya \& Gündoğdu, 2009) was developed to obtain data. For the development of the scale, a thorough literature review related to the characteristics of learning environments and democratic values was done. In the literature review, especially the characteristics of the constructivist learning environments were given of primary importance. Secondly, the characteristics of democratic learning environments and democratic values were searched. Democratic values such as 'justice, critical thinking, shared understanding, acceptance of differences and different ideas, possibilities, appreciation-respect and autonomy' were taken into consideration. Finally, an association between the characteristics of the constructivist learning environment and the democratic environment was made. For example, in constructivist approach learners are encouraged to make their own decisions in learning since autonomy is one of the aspects of democratic values. In this case, learners' decision-making for their learning is associated with autonomy and an item called 'learners make their own decisions for learning' was added to the item pool. At the end of this process approximately 90 items were formed. A five-point Likert scale labeled as 'I strongly agree (5) $\rightarrow$ I strongly disagree (1)' was used in this study. For the content validity, the draft version of the scale was reviewed by the experts from the Educational Sciences and Language Departments. They appraised the items on the basis of 
ambiguity, relevance and sentence structure. After these processes some items were eliminated and the scale was reduced to 66 items. The scale, then, was applied to the sample group which was selected after the learning process. Followings are the sample items that represent three of the seven factors in the scale:

First factor of the scale: Justice

Sample item: Groups are fair in peer evaluation

Third factor of the scale: Learner autonomy

Sample item: Learners take responsibilities of their own thinking and learning Seventh factor of the scale: Critical thinking

Sample item: Learners can ask their instructors the reason why they are learning that particular subject

Data obtained after the implementation were analyzed in SPSS program for validity and reliability purposes. After the factor analysis the scale was transformed into seven factors whose eigen value is above 1 . The first factor accounts for $10,164 \%$; the second factor accounts for $8,93 \%$, the third factor accounts for $8,804 \%$, the fourth factor accounts for $8,080 \%$, the fifth factor accounts for $7,285 \%$, the sixth factor accounts for $6,755 \%$ and the seventh factor accounts for $4,44 \%$ of the total variance. These seven factors accounted for $54,48 \%$ of the total scale.

In this study, item loading 0,40 and above is taken as a criteria to determine the factor loadings. The factor of each item in the table varies between the values of 0,416 and 0,820 . The shared variance of factors (except items 2 and 18) varies between the values of 0,414 0,734. At the end of these processes the first factor was named as 'shared understanding', the second factor as 'independence-autonomy', the third factor as 'possibility', the fourth factor as 'appreciation-respect', the fifth factor as respect for ideas-acceptance of differences; the sixth factor as 'critical thinking' and the seventh factor as 'justice'. The first factor has 13 items; the second factor has 10, the third factor has 9; the fourth, fifth and sixth factors have 7 and the last factor has 3 items. The scale has total 56 items (Bay, Kaya, Gündoğdu \& Karakaya, 2009).

The reliability coefficients of the scale were also calculated. The table below shows the reliability coefficients of each item and the scale. Internal consistency coefficients above .60 for scales are considered as sufficient (Kulaksizoglu et al, 2003). The reliability coefficients of 
factors varied between 0,78 and 0,89 and the reliability coefficient of the total scale was found as 0.95 .

Table 2. The reliability coefficients of the scale

\begin{tabular}{lc}
\hline Dimensions & Cronbach's Alpha \\
\hline Shared Understanding & 0.89 \\
Independence \& Autonomy & 0.85 \\
Possibility & 0.86 \\
Appreciation \& Respect & 0.86 \\
Acceptance of Differences & 0.87 \\
Critical thinking & 0.82 \\
Justice & 0.78 \\
& \\
\hline
\end{tabular}

Procedure

This study is part of a part of a more extensive project entitled 'the evaluation of the practices based on the constructivist approach in teacher education'. As part of this project, activities based on the constructivist approach in pedagogy program for prospective teachers are carried out currently.

For this study, learning environments which supported democratic values such as learner independence, appreciation, justice, equity, freedom, autonomy, respect for different ideas, acceptance of differences, shared understanding, collaborative work, responsibility and critical thinking were established for prospective teachers. In these learning environments learners carried out the pre-planned authentic tasks with their peers in groups that they have chosen to be in. The researchers played 'scaffolder' roles and learners participated in self and peer evaluations in this process as well. At the end of the semester, the researchers asked prospective teachers to submit their perceptions through a scale. All procedures were administered similarly in all departments.

\section{Design and Statistical Analysis}

For the analysis of the data obtained in the research process first of all means and standard deviation values were calculated. Then the items in each dimension were listed from highest mean to the lowest. For the analysis of the findings values between 1.00-1.80 was accepted 'very negative, values between 1.81-2.60 were accepted 'average', values between 3.41-4.20 were accepted ' positive' and values between 4.21-5.00 were accepted 'very posi- 
tive'. Later the general means of all items were found and differences between graphics and the items were displayed. Pearson moment correlation coefficients were calculated in order to determine the correlation between the dimensions.

\section{Results}

In this study, the perceptions of prospective teachers on the democratic aspects of the constructivist learning environments were sought and 'Democratic Constructivist Learning Environment' scale was applied. The findings of the study are as follows.

Perceptions of prospective teachers on whether or not constructivist learning environments facilitate 'appreciation \& respect'

It is important that teachers in learning environments are respected and positive learner behaviors are rewarded. In this research learners were found to perform this way in the process. The responses of the prospective teachers are as follows:

Looking at the table it can be seen that in this learning environment learners' ideas which serve learning process are respected $(\bar{X}=4.37)$; ideas are listened to $(\mathrm{x}=4.38)$, learners are made to feel important $(\bar{X}=4.41)$ and learners are respected $(\bar{X}=4.56)$. The total mean score of the items related to this dimension is calculated as $(\bar{X}=4, .45)$. According to this finding the perceptions of prospective teachers on this dimension is 'very positive' and constructivist learning environments facilitate appreciation and respect.

Table 3. Scores related to 'appreciation-respect'

\begin{tabular}{|c|c|c|}
\hline Item & $\bar{X}$ & $s d$ \\
\hline Ideas which serve learning process are respected & 4.37 & .759 \\
\hline Ideas are effectively listened to. & 4.38 & .826 \\
\hline We are made to feel important in this learning environment & 4.41 & .742 \\
\hline There is an opportunity for improving respect & 4.45 & .785 \\
\hline There is no any pressure on students by the teacher & 4.51 & .759 \\
\hline Ideas of learners are taken into consideration by the teacher & 4.52 & .692 \\
\hline Learners are respected & 4.56 & .644 \\
\hline In Total & 4.45 & \\
\hline
\end{tabular}


Perceptions of prospective teachers on whether or not constructivist learning environments facilitate 'critical thinking'

In this study findings related to the perceptions of prospective teachers on whether or not constructivist learning environments facilitate 'critical thinking' are as follows:

Table 4. Scores related to 'critical thinking'

\begin{tabular}{|c|c|c|}
\hline Item & $\overline{\bar{X}}$ & $s d$ \\
\hline Learners can criticize their instructor & 4.02 & 1.12 \\
\hline $\begin{array}{l}\text { Learners can ask their instructors the reason why they are learning } \\
\text { that particular subject }\end{array}$ & 4.37 & .836 \\
\hline $\begin{array}{l}\text { Learners can express their opinions about teaching methods and } \\
\text { techniques that their instructor is using. }\end{array}$ & 4.43 & .795 \\
\hline Learners can criticize the learning process & 4.45 & .785 \\
\hline Learners have opportunities for critical thinking & 4.51 & .759 \\
\hline Learners are encouraged for multiple points of view & 4.58 & .661 \\
\hline Everyone has the right to defend their own rights & 4.59 & .706 \\
\hline In Total & 4.42 & \\
\hline
\end{tabular}

The findings related to critical thinking reveal that everyone has the right to defend their own rights $(\bar{X}=4.59)$; learners are encouraged for multiple points of view $(\bar{X}=4.58)$; learners have opportunities for critical thinking $(\bar{X}=4.51)$; learners can criticize the learning process $(\bar{X}=4.45)$; learners can express their opinions about teaching methods and techniques that their instructor is using $(\bar{X}=4.43)$; and learners can ask their instructors the reason why they are learning that particular subject $(\bar{X}=4.37)$. It can be seen that prospective teachers are also 'very positive' in their perceptions on this dimension.

Perceptions of prospective teachers on whether or not constructivist learning environments facilitate 'shared understanding'

In this study learners are given the opportunity to work collaboratively and establish shared understanding in learning environments. At the end of this process the perceptions of learners on this issue are as follows. The findings below show that in constructivist learning environments group members enjoy working together $(\bar{X}=4.25)$; group members meet their responsibilities in group work $(\bar{X}=4.29)$; learners feel that they belong to a group during activities $(\bar{X}=4.31)$; learners participate in decisions related to the learning process $(\bar{X}=4.33)$. Learners can build shared understanding for their work $(\bar{X}=4.43)$; and exchange ideas in team 
work $(\bar{X}=4.61)$. Finally the findings show that these learning environments support 'shared understanding' and the perceptions prospective teachers $(\bar{X}=4.42)$ are 'very positive' about this issue.

Table 5. Scores related to 'shared understanding'

\begin{tabular}{|c|c|c|}
\hline Item & $\bar{X}$ & $s d$ \\
\hline Group members enjoy working together & 4.25 & .840 \\
\hline Group members meet their responsibilities in group work & 4.29 & .930 \\
\hline Learners have the opportunity to evaluate the other learners & 4.30 & .922 \\
\hline Learners feel that they belong to a group during activities & 4.31 & 907 \\
\hline Learners participate in decisions related to the learning process & 4.33 & .900 \\
\hline Learners have a voice in evaluation processes & 4.34 & 916 \\
\hline Collaborative provides opportunities for different ideas & 4.41 & .782 \\
\hline Learners can build common understanding for their work & 4.43 & 670 \\
\hline Group members can have common ideas on their work & 4.50 & .723 \\
\hline All work is done through team & 4.53 & .735 \\
\hline Group members share the conclusion they have come up with & 4.58 & .655 \\
\hline Groups exchange ideas in team work & 4.61 & .703 \\
\hline Good suggestions are supported in teams & 4.62 & .661 \\
\hline In Total & 4.42 & \\
\hline
\end{tabular}

Perceptions of prospective teachers on whether or not constructivist learning environments facilitate 'possibility'

As discussed in the theoretical background of this study there is relativity in all processes. The responses of the learners to the items related to this dimension are as follows:

Table 6. Scores related to 'possibility'

\begin{tabular}{lcc}
\hline Item & $\bar{X}$ & \multicolumn{1}{c}{ sd } \\
\hline Certainty is not accepted in this learning environment & 4.15 & .963 \\
Knowledge is assumed to be relative in learning process & 4.22 & .925 \\
Works of learners cannot be compared with each other & 4.24 & .996 \\
It is assumed that learners' ideas are correct & 4.31 & .776 \\
Learning environments present multiple representations of reality & 4.34 & .810 \\
It is assumed that in this learning environment learners' cognitive & 4.38 & .799 \\
structures are different & & \\
It helps learners reflect knowledge in different ways & 4.43 & .744 \\
Any kind of method, material etc that serve learning process can be used & 4.48 & .781 \\
It is assumed that learners have different learning levels & 4.51 & .770 \\
& In Total & 4.34 \\
\end{tabular}

The findings reveal that certainty is not accepted in the learning environment $(\bar{X}=4.15)$; knowledge is assumed to be relative in learning process $(\bar{X}=4.22)$ and learning 
environments present multiple representations of reality $(\bar{X}=4.34)$. The general mean of this dimension is found as ' 4.34 ' This finding show that perceptions on the constructivist learning environments in terms of 'possibility' are 'very positive'.

Perceptions of prospective teachers on whether or not constructivist learning environments facilitate 'acceptance of differences \& respect for different ideas'

It is important that in democratic learning environments learners tolerate criticisms and respect different ideas. The findings related to the perceptions of prospective teachers on the acceptance of differences in constructivist learning environments are as follows:

Table 7. Scores related to 'acceptance of differences-respect for different ideas'

\begin{tabular}{lcc}
\hline Item & $\bar{X}$ & \multicolumn{1}{c}{$\boldsymbol{s \boldsymbol { d }}$} \\
\hline Groups tolerate any kind of criticism directed at them & 4.07 & 1.038 \\
They respect opposite ideas & 4.15 & .995 \\
They accept and respect different ideas & 4.20 & .880 \\
The ideas of other groups are met positively & 4.28 & .893 \\
Group members respect each others' ideas and efforts & 4.30 & .931 \\
Conflicts in groups are solved within groups & 4.32 & .968 \\
The ideas of other groups during presentations are respected & 4.34 & .841 \\
& In Total & 4.23 \\
\hline
\end{tabular}

The findings presented at the table show that groups in constructivist learning environments tolerate any kind of criticism directed at them and respect different ideas. Besides, the perceptions reveal that in this learning environment conflicts in groups are solved within groups and the ideas of other groups during presentations are respected and group members respect for each others' ideas and efforts. The mean score of this dimension is ' 4.23 ' which shows that prospective teachers are 'very positive' about this dimension.

Perceptions of prospective teachers on whether or not constructivist learning environments facilitate 'independence-autonomy'

In constructivist learning environment learners' independence-autonomy is supported. In these learning environments it is important that learners are responsible for their own learning. The perceptions of the prospective teachers regarding this issue are as follows:

In constructivist learning environments it is important that learners are given responsibilities for their own learning. The findings related to this dimension reveal the perceptions on 
the following items are 'positive': 'learners chose and study their subjects independently'; 'learners make decisions on their own learning (self-evaluation)'; 'learners make decisions on the learning process together with their teacher'; 'learners evaluate their own learning related to knowledge, attitude and belief' and 'learners chose alternatives presented in the learning process.' Besides, it can be seen that perceptions on the items numbered 18, 22, 23, 24 are 'very positive'. The general arithmetic mean $(\bar{X}=4.22)$ shows that prospective teachers' perceptions on this dimension are 'very positive' and these learning environments facilitate learner independence.

Table 8. Scores related to the perceptions on 'independence'

\begin{tabular}{|c|c|c|}
\hline Item & $\bar{X}$ & $S d$ \\
\hline Learners chose and study their subjects independently & 3.85 & 1.205 \\
\hline Learners evaluate their own learning & 3.97 & 1.139 \\
\hline $\begin{array}{l}\text { Learners make decisions on the learning process together with their } \\
\text { teacher }\end{array}$ & 4.12 & 1.031 \\
\hline Learners make decisions on their own learning (self-evaluation) & 4.16 & .956 \\
\hline $\begin{array}{l}\text { Learners evaluate their own learning based on knowledge, attitude and } \\
\text { belief }\end{array}$ & 4.17 & .904 \\
\hline Learners chose alternatives presented in the learning process & 4.18 & .907 \\
\hline Learners have autonomy & 4.35 & .789 \\
\hline $\begin{array}{l}\text { Decisions and responsibilities related to learning belong to learners in the } \\
\text { guidance of the teacher }\end{array}$ & 4.39 & .802 \\
\hline Learners take responsibilities of their own thinking and learning & 4.46 & .780 \\
\hline \multirow[t]{2}{*}{$\begin{array}{l}\text { Opportunities are presented to learners to chose their own study group } \\
\text { members }\end{array}$} & 4.56 & .702 \\
\hline & 4.22 & \\
\hline
\end{tabular}

Perceptions of prospective teachers on whether or not constructivist learning environments facilitate 'justice'

One of the aspects of democratic constructivist learning environments is 'justice'. The findings related to the perceptions of prospective teachers on whether or not constructivist learning environments are just are as follows:

Table 9. Scores related to the perceptions on 'justice'

\begin{tabular}{lcc}
\hline Item & $\bar{X}$ & $\boldsymbol{S d}$ \\
\hline Groups are just to their peers in evaluations & 3.60 & 1.223 \\
Learners are objective in self-evaluations & 3.94 & 1.114 \\
There is justice in every kind of activity & 4.59 & .706 \\
& In Total & 4.04 \\
\hline
\end{tabular}


The findings show that the mean score of the item 'groups are just to their peers in evaluations' is ' 3.60 '; the mean score of the item 'learners are objective in self-evaluations' is ' 3.94 '; and the mean score of the item 'there is justice in every kind of activity' is '4.59.' The findings in general show that prospective teachers are 'positive' about this issue and think that constructivist learning environments are 'just'.

The differences in the ideas of prospective teachers related to the seven dimensions reflected in the first research question can be easily followed in the graph below.

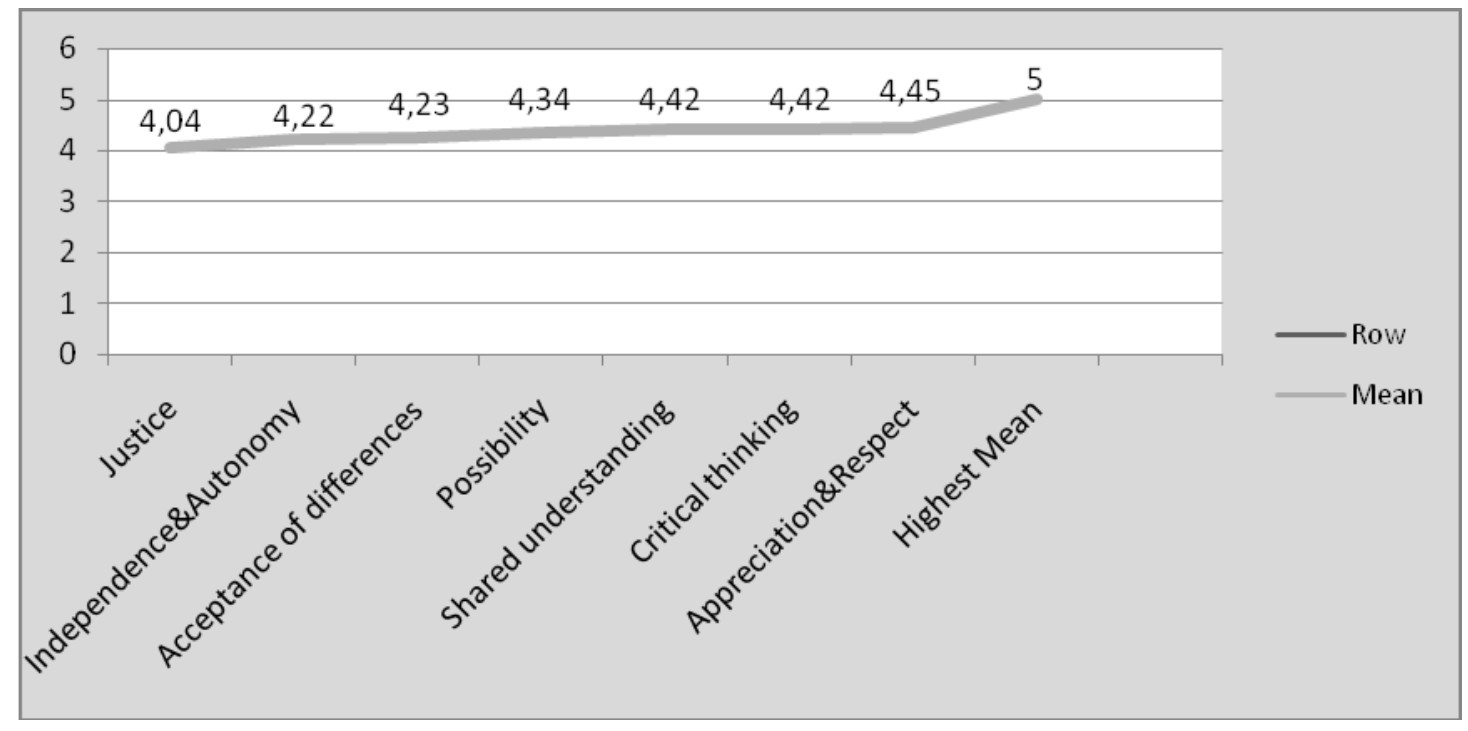

Graph 1. Mean values regarding the dimensions in the scale

It is seen in the graph that 'justice' has the least average mean $(\bar{X}=4.04)$ in terms of democratic dimensions while 'appreciation \& respect' for learners has the highest mean score of 4.45. It is also seems from the graph that that there is not much differentiation in these dimensions either. Considering that the '5.00' is the highest mean score. It is also understood that all dimensions received 'very positive' responses from the prospective teachers except for the 'justice', although it still remains within the positive category.

The correlation between the democratic dimensions of constructivist learning environments

In order to determine if there is any correlation between the factors determined in the scale, Pearson moments correlation coefficients were calculated. The findings are as follows: 
Table 10. Correlation between the factors

\begin{tabular}{|c|c|c|c|c|c|c|c|}
\hline & $\begin{array}{l}\text { Shared } \\
\text { understanding }\end{array}$ & $\begin{array}{c}\text { Independ- } \\
\text { ence \& } \\
\text { Autonomy }\end{array}$ & Possibility & $\begin{array}{c}\text { Apprecia- } \\
\text { tion \& } \\
\text { respect } \\
\end{array}$ & $\begin{array}{c}\text { Acceptance } \\
\text { of differ- } \\
\text { ences }\end{array}$ & $\begin{array}{l}\text { Critical } \\
\text { thinking }\end{array}$ & Justice \\
\hline $\begin{array}{l}\text { Shared } \\
\text { understanding }\end{array}$ & - & $.571 *$ & $.617^{*}$ & $.499^{*}$ & $.586^{*}$ & $.550 *$ & $.210 *$ \\
\hline $\begin{array}{l}\text { Independence } \\
\text { \& Autonomy }\end{array}$ & & - & $.604 *$ & $.500 *$ & $.448 *$ & $.528 *$ & $.152 * *$ \\
\hline Possibility & & & - & $.575^{*}$ & $.502 *$ & $.602 *$ & $.223 *$ \\
\hline $\begin{array}{l}\text { Appreciation } \\
\text { \& respect }\end{array}$ & & & & - & $.468^{*}$ & $.548^{*}$ & $.269 *$ \\
\hline $\begin{array}{l}\text { Acceptance of } \\
\text { differences }\end{array}$ & & & & & - & $.536^{*}$ & $.347 *$ \\
\hline $\begin{array}{l}\text { Critical } \\
\text { thinking }\end{array}$ & & & & & & - & $.193 *$ \\
\hline Justice & & & & & & & - \\
\hline
\end{tabular}

${ }^{*} \mathrm{p}<.01 \quad * * \mathrm{p}<.05$

As can be seen in the Table, except the correlation between justice and independence $(p<.05)$ there is a positive and meaningful correlation between other sub dimensions $(\mathrm{p}<.01)$.

\section{Discussion and Conclusion}

This study aimed to examine the democratic aspects of constructivist learning environments. Findings regarding the prospective teachers' perceptions revealed that constructivist learning environments facilitate 'justice'. In these learning environments it was reported that participation of learners in peer and self-evaluations increase justice in the learning processes. As was suggested by Rochera (2007) after a study investigating self-regulation and assessment relation, powerful and well designed assessment situations promote the selfregulatory skills of learners which lie at the heart of the constructivist learning process. The perceptions of the prospective teachers also showed that in constructivist learning environments learners' opinions which are thought to serve the learning process are respected, ideas are listened to, learners are respected, and learners are not pressurized, in other words, in these processes there is respect and appreciation.

In this study, in order to support learners participants were given the opportunity to choose their topics and team members. The findings showed that these processes have been successful and these learning environments supported autonomy. One of the important aspects of constructivist learning environments is that learners build a shared understanding. In the process of collaborative work learners should implement their assigned tasks. In this process it is important that learners make decisions as a team and build a common understanding. 
These characteristics are crucial for raising a human model suitable for this modern era. The findings based on the perceptions of prospective teachers in this study showed that constructivist learning environments served for this aim. In the process of common understanding it is also vital that learners are respected and their differences are accepted. Regarding this issue, prospective teachers appeared very positive and they thought that the constructivist learning environment accepted differences and supported different ideas which is the base for democratic ethos .

As Tanner and Tanner (1995) state, human life depends on interaction. Schools should help their students to have interactions with their friends and provide them a common social life in order to help them obtain the most quality knowledge. Schools with students who undergo rich and fruitful experiences can also facilitate respect and appreciation which are the most important aspects of democracy. According to Dewey (1966), if schools foster local economic life styles with competitive social relations cannot improve interactive social relationships required for the new emerging democracy.

One of the advanced cognitive skills that human beings should possess today is "critical thinking'. It is important to improve critical thinking in constructivist learning environments. In this study, the data collected the perceptions of the prospective teachers showed that these learning environments contribute a great deal to the critical thinking of learners.

One of the variables of democratic learning environments is possibility. There is no certainty in the era we live in and everything is relative. This is the main philosophy of constructivist approach. For this reason, in constructivist learning environments it is assumed that every individual is different from one another. Besides in this approach there is an emphasis on contextuality. A teacher who teaches the same subject in different classes may come up with different results due to the contextual settings. Such a perspective is important in a democratic environment. The findings of this study showed that 'possibility' factor appeared to be a crucial basis of the constructivist learning environment.

This study also examined if there was correlation between the variables of the democratic classroom environment. Positive and meaningful correlation was found between all the dimensions. This result shows that all the variables of democratic learning environment included in the research instrument are related. In a study conducted by Şahin (2004) the pro- 
spective teachers found their classroom environment democratic in 'average' level in terms of collaborative learning, justice and independence. The study carried out by Gürşimsek and Göregenli (2004) showed that the democratic value of 'justice' is responded as 'average' and 'participation in decisions' is responded as 'low'.

Yet these findings do not support the findings of this current study. In this study the responses of the prospective teachers are more positive maybe because the learning environments are constructed by the researchers unlike the other studies which are carried out in natural learning environments. This study reflected the perceptions of prospective teachers after a constructivist implementation at higher education only. Future research should examine differences in the perceptions regarding democratic principles across different courses, those that are constructivist and those that are not.

\section{References}

Abdal-Haqq, I. (1998). Constructivism in teacher education: considerations for those who would link practice to theory: Clearinghouse on Teaching and Teacher Education, Washington DC.

Audigier, F. (2000). Basic concepts and core competencies for education for democratic citizenship: An initial consolidated report. Strasbourg: Council of Europe. Retrieved on March, 1, 2000, from http://www.ibe.unesco.org/regional/SEE/SEEpdf/audigier.pdf 12.06.2006.

Bahar, M., Nartgün, Z., Durmuş, S. \& Bıçak, B. (2006). Geleneksel-alternatif ölçme ve değerlendirme. ögretmen el kitabl. (Traditional-Alternative Measurement and Evaluation Teacher Handbook) Ankara: Pegem.

Bay, E. Kaya, H. İ. \& Gündoğdu, K. (In Press, 2010). Developing democratic constructivist learning environment scale. E-Journal of New World Sciences Academy.

Bay, E., Kaya, H.İ., Gündoğdu, K. \& Karakaya, Ş (2009, June). The perceptions of prospective teachers on the democratic aspects of the constructivist learning environment. Paper presented at The International Symposium on Democracy and Democracy Educa- 
tion in Europe. Çanakkale Onsekiz Mart University, Çanakkale, Turkey, 11-12 June, 2009.

Boud, D. (1995). Assessment and learning: contradictory or complementary? In P. Knight (Ed.) Assessment for Learning in Higher Education. London: Kogan Page Campbell, D. E. (2000). Choosing democracy (2 $2^{\text {nd }}$ ed.). Upper Saddle River: Merrill.

Coll, C., Rochera, M. J., Myordomo, R. M. \& Naranjo, M. (2007). Continuous assessment and support for learning: An experience in educational innovations with ICT support in higher education. Electronic Journal of Research in Educational Psychology, 13(5), 783-804. Retrieved January 12, 2010 from http://www.investigacion-psicopedagogica.org/revista/new/english/LeerArticulo.php

Dearing, R. (1997). Higher education in the learning society: Report to the National Committee of Enquiry into Higher Education. London: HMSO.

Demirhan, C. \& Demirel, Ö. (2002) Program geliştirmede proje tabanlı öğrenme yaklaşımı (Project based learning approach in curriculum development). Abant İzzet Baysal Üniversity Faculty of Education Journal. 3(5), 48-61.

Dewey, J. (1966) Democracy and Education. An introduction to the philosophy of education. New York: Free Press.

Dockery, K. (2008). Constructivism: Theory and implementation defined. Retrieved December 12, 2008 from http://dspace.nmt.edu/dspace/bitstream/10136/118/2/Kath\%20Dockery\%20Independe nt $\% 20$ Study\%20A.pdf

Effie, M. (2004). How convincing is alternative assessment for use in higher education? Assessment \& Evaluation in Higher Education 29(3), 311- 321

Gagnon, G. \& Collay, M. (2006). Constructivist learning design for classroom teaching. Thousand Oaks: Corwin Press.

Gerzon, M. (1997). Teaching democracy by doing it! Educational Leadership, 54(5), 6-11.

Glickman, C. D. (1998). Revolution, education, and the practice of democracy. The Educational Forum. 63(1), 6-22.

Goodman, J. (1989). Education for critical democracy. Journal of Education, 171(2), 88-117. Gray, A. (1997). Contructivist teaching and learning. SSTA Research Centre Report. 
Gürşimşek I. \& Göregenli M. (May, 2004). Öğretmen adayları ve ögretmenlerde demokratik tutumlar, değerler ve demokrasiye ilişkin inançlar (Beliefs on democracy, values and attitudes of prospective teachers and teachers).International Democracy Education Symposium, Çanakkale Onsekiz Mart University, 20-21 May, 2004.

Herrington, J. \& Kervin, L. (2007).Authentic learning supported by technology: Ten suggestions and cases of integration in classrooms. Educational Media International. 44(3), 219-236.

Holmes, E. E. (1991). Democracy in elementary school classrooms. Social Education, $55,176-178$.

Honebein, P. (1996). Seven goals for the design of constructivist learning. Retrieved April 04, 2007 from http://cter.ed.uiuc.edu/JimLCourses/edpsy490i/su01/readings/honebein.htm

İşman, A. (2003). Öğretim teknolojileri ve materyal geliştirme (Instructional technologies and material development). İstanbul: Değişim Publishing.

Jonassen, D. H. (1994). Thinking technology: Toward a constructivist design model. Educational Technology Research and Development, 34(4), 34-37.

Kaye, A. R. (1992). Learning together apart. In A. R. Kaye (Ed), Collaborative learning through computer conferencing (pp. 1-24). London: Springer-Verlag.

Kesal, F. \& Aksu, M. (2005). Constructivist learning environment in ELT Methodology II courses. Hacettepe University Faculty of Education Journal. 28, 118-126.

Kıncal, R. Y. \& Işık, H. (2003). Demokratik eğitim ve demokratik değerler (democratic education and democratic values). Educational Research Journal. 11, 54-58.

Kim, B. (2001). Social Constructivism. In M. Orey (Ed.). Emerging perspectives on learning, teaching, and technology. Retrieved April 21, 2006 from http://projects.coe.uga.edu/epltt

Koç, G. (2007). Yapılandırmacı öğrenme kuramı (Constructivist learning theory). Eğitim Psikolojisi (Constructivist learning theory, ed. Ayten Ulusoy). Ankara: Anı Publishing.

L. Hsiao \& J.W. Daphne (2007). CSCL theories: computer-supported collaborative learning. Retrieved February 12, 2008 from www.edb.utexas.edu/csclstudent/dhsiao/theories.html 
LeBlanc, P. R., \& Skaruppa, C. (1997). Support for democratic schooling: classroom level change via cooperative learning. Action in Teacher Education, 19, 28-38.

Lee, H. S. \& Butler, N. (2003). Making authentic science accessible to students. International Journal of Science Education, 25(8), 923-948.

Lester, N.B. \& Onore, C.S. (1990). Learning Change: One school district meets language across the curriculum. Portsmith, NH: Boynton/Cook Publishers.

Moallem, M. (2001).Applying constructivist and objectivist learning theories in the design of a web-based course: implications for practice. Educational Technology \& Society, 4(3), 113-125.

Murphy, E. (1997). Characteristics of constructivist teaching and learning. constructivism:from Philosophy to Practice. Retrieved December 02, 2007 from http://www.cdli.ca/ ehnurphv/emurphv/cle.html

O’Hair, M. J., McLaughlin, H. J. \& Reitzug, U. C. (2000). Foundations of democratic education. Orlando: Harcourt College Publishers.

Oğuz, A. (2005). Yükseköğretimde yapılandırmacı öğrenme ortamları (Constructivist learning environments in higher education). Educational Research Journal, 17, 162-174.

Özden, Y. (2003). Öğrenme ve ögretme (Learning and teaching, $6^{\text {th }}$ ed.). Ankara: PegemA.

Pankratius, W. J. \& Young, M. W. (1995). Perspectives on education: a constructivist a approach to an introductory course. Education, 115( 3), 363-368.

Passe, J. (1996). When students choose content. Thousands Oak: Corwin Press.

Postholm, M., B. (2006). The teacher's role when pupils work on task using ICT in project work. Educational Research, 48(2), 155- 175.

Radz, M. A. (1983). The school society: Practical suggestions for promoting a democratic school climate. In M. A. Hepburn (Ed.), Democratic education in schools and classrooms (pp. 67-87). Washington, DC: NCSS.

Rowland, S. ( 2003). Teaching for democracy in higher education. Teaching In Higher Education. 8(1), 89-101.

Saban, A. (2004). Öğrenme ve öğretme süreci: yeni teori ve yaklaşımlar (Learning and teaching process: new theory and approaches, $2^{\text {nd }} \mathrm{ed}$.). Ankara: Nobel.

Savaş, B. (2007). Yapılandırmacı öğrenme (Constructivist learning). In A. Kaya (Ed.). Eğitim Psikolojisi (Educational Psychology), pp. 535-561. Ankara: Pegem. 
Semerci, Ç. (2001). Oluşturmacılık kuramına göre ölçme ve değerlendirme (constructivist measurement and evaluation). Educational Sciences Journal in Theory and Practice, $1(2), 429-440$.

Soon, T., Apan, M. \& Huabing, Z. (2001). Knowledge construction in education: a webdatabase for building interactive 3d environments. Retrived February 17, 2008 from http://my.apan.net/meeting/downloads/ educationKnowledgeConst.PDF

Şahin, N. (May, 2004). COMU Sinıf Öğretmenliği öğretmen adaylarının demokratik sınıf ortamı ile ilgili görüşleri (COMU prospective classroom teachers' opinions on democratic classroom environment) International Democracy Education Symposium, Çanakkale Onsekiz Mart University, 20-21 May, 2004.

Şaşan, H. (2002).Yapılandırmacı öğrenme (constructivist learning). Lifetime Education Journal, 74, 49-52.

Tanner, D. \& Tanner, L. (1995). Curriculum development: Theory into practice.(3rd ed.) Columbus, OH: Prentice Hall.

Taras, M. (2001). The use of tutor feedback and student self-assessment in summative assessment tasks: towards transparency for students and for tutors. Assessment \& Evaluation in Higher Education, 26(6), 605-614.

Terhart, E. (2003). Constructivism and teaching: a new paradigm in general didactics? Journal of Curriculum Studies, 35(1), 25-44.

Tezci, E. \& Dikici, A. (2003). Yaratıcı düşünmeyi geliştirme ve yapılandırmacı öğretim tasarımı (developing critical thinking and constructivist instructional design). Firat University Social Sciences Journal, 13(1), 251-260.

Tynjälä, P. (1999). Towards expert knowledge? a comparison between a contructivist and a traditional learning environment in university. International Journal of Educational Research, 31(5), 357- 442.

Tynjala, P. \& Hakkinen, P. (2005). E-learning at work: Theoretical underpinnings and pedagogical challenges. The Journal of Workplace Learning. 17(5), 318-336.

Villach, M. J. R. \& Llanos, M. N. (2007). Fostering self-regulated learning in an assessment situation. Electronic Journal of Research in Educational Psychology, 13(5), 805-824. Retrieved January 11, 2010 from http://www.investigacion-psicopedagogica.org/revista/new/english/LeerArticulo.php 
Erdal Bay et al.

Yaşar, Ş. (1998). Yapısalcı kuram ve öğrenme öğretme süreci (constructivist theory and learning teaching process). Anadolu Üniversity Faculty of Education Journal. 8(1-2), $8-75$. 